\title{
Renter Power For Better Living: Cover with Acknowledgements and References ${ }^{1}$
}

Mary N. Harrison ${ }^{2}$

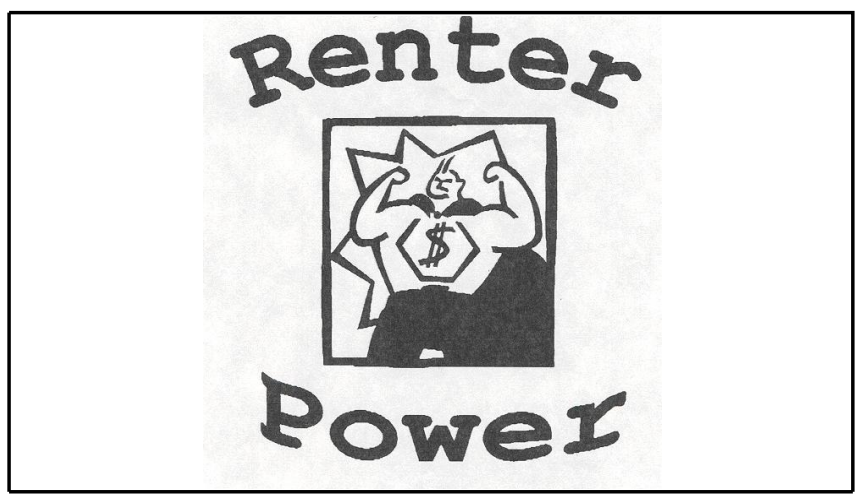

For Better Living.

\section{Acknowledgments}

Special thanks to:

- Deborah Boulware, Lake County Cooperative Extension Service.

- Kathleen Bryant, Orange County Cooperative Extension Service.

- Charna Cohn, Alachua County Affordable Housing Coalition.

- Christina Procise, Martin Cooperative Extension Service.
- Judy Wakefield, Indian River Cooperative Extension Service.

- Brenda Williams, Alachua County

Cooperative Extension Service.

\section{References}

Environmental Protection Agency (EPA). Ten Tips To Protect Children From Pesticide And Lead Poisoning Around The Home.

Hammer, Marie. Healthy Homes: A Guide to Successful Home Management. Cooperative Extension, IFAS, University of Florida.

Harrison, Mary N. Landlords and Tenants: Rules and Regulations, Cooperative Extension, IFAS, University of Florida, Gainesville.

Oregon State University Extension Service. A Clean and Healthy Home.

Peart, Virginia. My Home Book Cooperative Extension, IFAS, University of Florida.

1. This document is FCS5230-01, one of a series of the Family Youth and Community Sciences Department, Florida Cooperative Extension Service, Institute of Food and Agricultural Sciences, University of Florida. Original publication date June 2002. Revised December 2005. Visit the EDIS Web Site at http://edis.ifas.ufl.edu.

2. Mary N. Harrison, professor, Department of Family, Youth and Community Sciences, Cooperative Extension Service, IFAS, University of Florida, Gainesville, 32611.

The Institute of Food and Agricultural Sciences (IFAS) is an Equal Opportunity Institution authorized to provide research, educational information and other services only to individuals and institutions that function with non-discrimination with respect to race, creed, color, religion, age, disability, sex, sexual orientation, marital status, national origin, political opinions or affiliations. U.S. Department of Agriculture, Cooperative Extension Service, University of Florida, IFAS, Florida A. \& M. University Cooperative Extension Program, and Boards of County Commissioners Cooperating. Larry Arrington, Dean 
Procise, Christina. Safe Cleaning Products You Can Make. Martin County Cooperative Extension, IFAS, University of Florida.

Wakefield, Judy. A Clean Home. Indian River County Cooperative Extension, IFAS, University of Florida.

Wakefield, Judy. Don't Invite Insects Into Your Home. Indian River County Cooperative Extension, IFAS, University of Florida.

Prepared by: Mary N. Harrison, professor, Consumer Education, Department of Family, Youth and Community Science, University of Florida, and the Alachua County Affordable Housing Coalition. 